\title{
FA 技術
}

\section{マシンドライブの技術動 向}

\section{(釉東芝産業システム技術部 山田晃 \\ Technical Trend of Paper-Machine Drive System}

\author{
Akira Yamada \\ Toshiba Corporation
}

The "mill-wide system of pulp and paper industries", which improves the mill's overall efficiency, enable flexible production structure, save energy and so on, is introduced recentry.

To realize it TOSHIBA developed C. I. E. Integrated system, which inter-actively combined production planning and management by Computer (C), process control by Instrumentation control system (I), and Electrical drive equipment (E).

In this paper, we describe the advanced technology of electrical drive (E) portion, and explain how conventional paper machine drive equipment has been changed to new hardware, that is adopted to C. I. E. integrated system.

Modern paper machine drive system is consist of fully digital drive equipment, high performance programmable controller based master controller, and operator interface stations for manmachine communication. This system achieves high accuracy control as well as improvement operation efficiency.

And also we explain the recent tehnical trend of AC drive systems, which adopt power transister (GTR) and gate turn-off thyrister (GTO).

\section{1.はじめに}

紙パルプ産業では, 高度情報化社会の進展と内需拡 大基調により紙製品の需要が高まり, 設備増強はもち ろんのこと, 多品種小量生産への移行投資, 販売生産 管理システムの近代化への投資が行われている。製品 の多様化, 高付加価值化に対応するため, ミルワイド システムの導入が活発で, 当社では生産計画から製造 管理, プロセス計装制御, ドライブシステムまでの各 サブシステムを有機的に統合した一貫システムである CIE (Computer, Instrumentation, Electrical Equipment）統合システムを提供している。

本稿では, この CIE 統合システムを構成するマシン ドライブシステムの動向について述べる。

\section{CIE 統合システム}

国内のセクショナルドライブは 1951 年に $M G$ 方式
の抄紙機が稼働以来, サイリス夕駆動システムの適用, マイクロコンピュータ応用システム製品, インバータ 駆動システムの採用, CRT 保守監視装置などの技術変 遷を経て現在に至っており, 数多くのセクショナルド ライブシステムが稼働している。最近では特に半導体 技術とマイクロコンピュー夕技術の急速な進歩を背景 に, 抄紙機駆動装置は CIE 統合システムへの拡張性あ るハードウェア製品に変わってきた。

駆動装置のキーコンポネントとしては, ドライブ用 に全デジタル形駆動装置, 抄紙機ライン総括制御に高 機能プログラマブルコントローラ, マンマシンコミュ ニケーションにプログラマブルディスプレイを採用し, かつこれらすべてを伝送装置で結合して, 操業効率向 上を計ったシステムとなっている。

抄紙機ドライブシステムの最近の傾向は, 総合生産 管理体制の導入により操業機能及び管理項目が多様化 し, 取り扱う情報量が増大し, かつ熟練オペレータの 
減少という状況の中で, 高精度の制御特性ばかりでな く, 特に省力化, メインテナンスの容易性，および信 頼性向上に大きく目が向けられるようになってきてお ク, さらに銘柄別ドローの自動設定, 操業監視, 用具 のメンテナンスモニタなど, 操業効率を向上させるた めの各種機能を設けたシステムの要求が強く, 実用化 されている。

またミルワイド化が進み生産管理, 生産計画, 製造 プロセスの自動化, エネルギー・原料の管理など, トー タル的視野からの合理化を進めていく動向にあるため, 情報伝送のためのネットワークシステムが不可欠であ り, 機械設備に直結したドライブ装置はミルワイド化 への拡張性が要求される。

これを実現するため，当社は情報処理・計装・ドラ イブ電気制御をプロセス制御幹線 LAN 用いて結合 し，ミルワイド化への拡張を可能とした。

図 1 はCIE 統合を実現する製紙プラント総合管理 システムの 1 例で, 計装 $(\mathrm{I}) \cdot$ 電気 $(\mathrm{E}) \cdot$ 計算機 $(\mathrm{C})$ を高速伝送ライン (IEEE 802.4 MINI-MAP (Manufacturing Automation Protocol) に準拠した LAN) “ADMAP”で初めて密結合させた紙パ業界最新鋭の CIE 統合システムである。

調成・抄紙工程では計算機が $\mathrm{I} ・ \mathrm{E}$ のプロセスデータ を随時，かつ同一時刻のデータとして収集できるため， 生産実績デー夕や他の接続機器デー夕とも紐づけて一 元管理することが可能となった。こうしたデー夕管理 精度の向上は, 操業の安定化の面で大きなプラスと なっている。

\section{3. 最新鋭デジタル制御技術を駆使した ドライブシステム}

\section{1 システムの主幹制御機能}

CIE 統合システムを構成する最新銧の抄紙機ドライ ブのシステム構成を図 2 に示す。主幹制御コントロー ラと各セクションの全デジタル形制御盤, および現場 操作机間は相互をデー夕伝送網で結合したシステムで あり,さらにビジュアル化して操作や保守が容易に行 えるシステムである。また主幹制御部は上位 $\mathrm{CPU}$ と 結合可能な構成をとっており, 拡張性のあるシステム となっている。

抄紙機のライン総括制御用の主幹コントローラでは ・ライン速度演算

$$
\text { ラインドライブシーケンス }
$$

・各セクションドロー基準演算機能（連動ドロー演算 を含む)

・張力制御演算

たるみとり，たるみ付け演算機能

・ドローメータ機能

リール巻取長演算

・マンマシンインターフェイスサポート

といった基本機能のほかに

・塗工機の伸び率制御

銘柄別ドロー設定・変更制御

・自動紙切り制御

通紙速度自動設定制御

・リール自動枠替シーケンス

リール加圧演算

・保守監視

用具管理
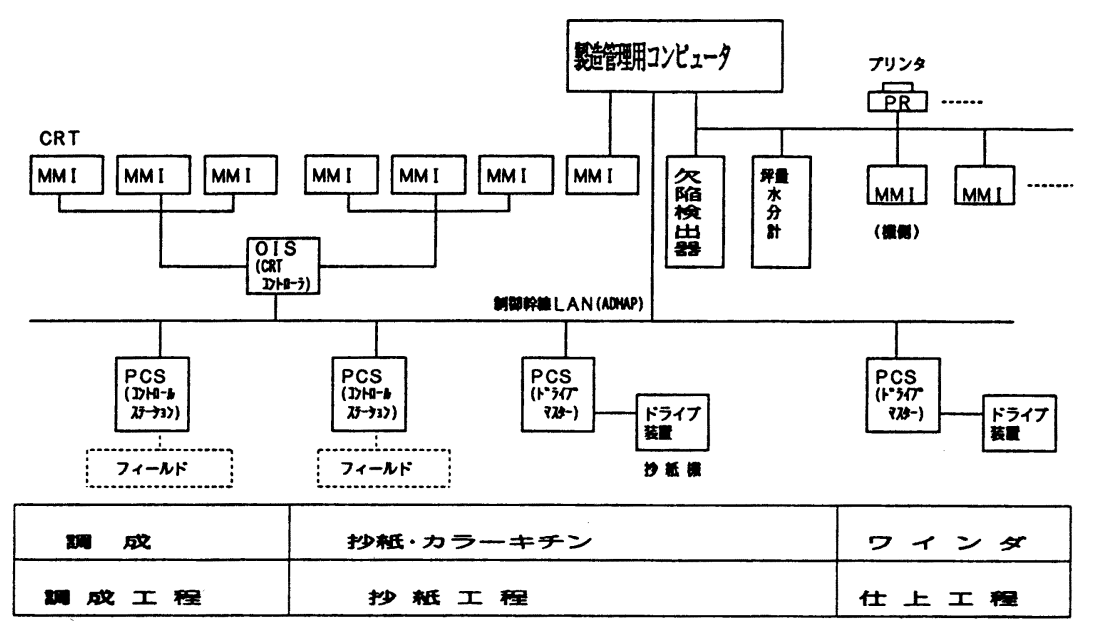

図 1 CIE 統合システム構成 


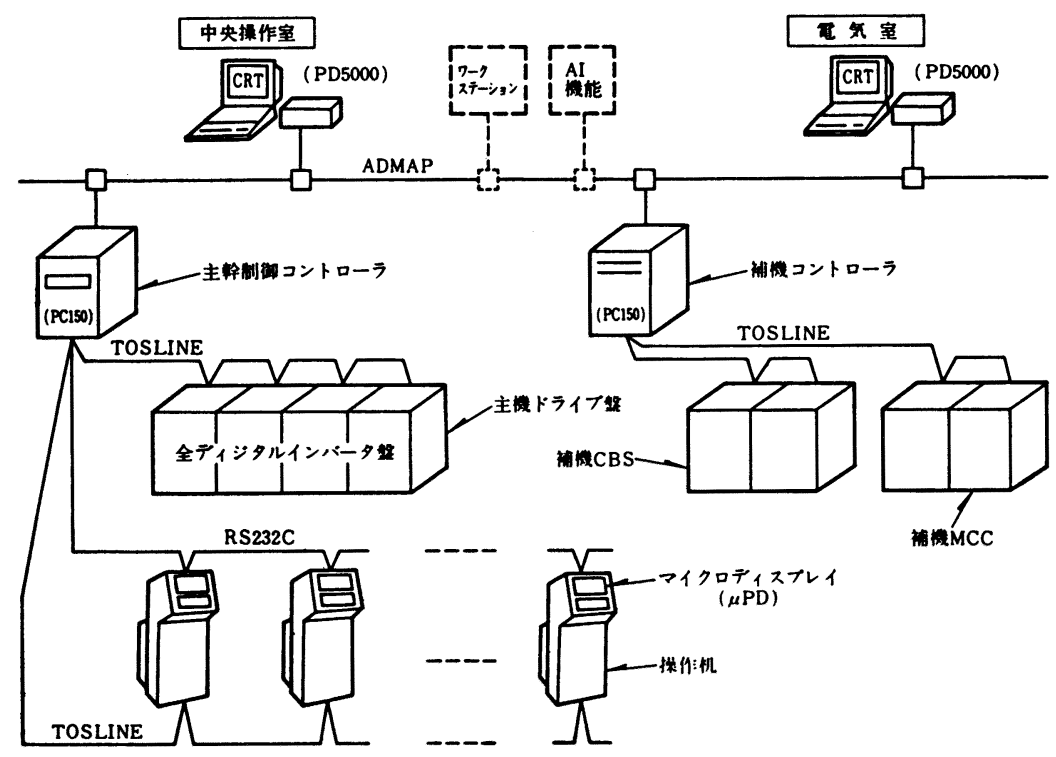

図 2 抄紙機ドライブシステム構成

などの特殊制御機能が用意され，豊富な実績から得な ノウハウを基にプロセス・マシン特性や操業方法に マッチしたシステム機能を標準化して, 紙切れ頻度の 非常に少ない抄紙機ドライブシステムを提供している。

仕上設備（ワインダ, リリーラ, コータ, スーパー カレンダなど）のラインドライブでも主幹制御コント ローラは

・ドライブシーケンス

張力制御

・速度基準設定 ( $\mathrm{S}$ カーブ)

高精度の定尺制御

・シート補修制御

残径制御

・トルク差制御

テーパ張力制御

・リールセンタドライブ制御・(自動界磁制御, 加減速 補償・メカロス補償制御)

などライン全体のシステム機能を受けもち, 品質向上 に必要な張力変動の少ない高精度の制御を実現してい る。

また産業用コンピュータ G $200 \mathrm{~V}$ と結合すること により, ワークステーション機能を充実した CE 融合 の仕上げ管理システム（図３）も構築できる。

一方, マンマシンコミュニケーション用として中央 操作室に設置された CRT では, 運転状態の表示・監 視, 各種機械データの表示, およびタッチスクリーン による各種デー夕の設定が可能であるばかりでなく，
各種のトレンド表示, アラームサマリー機能により, 紙切れ発生時の原因究明や故障発生時の早期対策を可 能としている。

CRT 機能の 1 例は次のとおりである。

(1)各セクションの起動条件, 運転条件の成立, 不成 立を表示

(2)各セクションの運転状態表示

(3)各セクションの設定ドロー, 実ドロー表示

(4)各ロールの負荷率, マスタ/ヘルパの負荷分担率 表示

(5)抄速, 抄速変更率, および銘柄別ドローパターン の登録と設定

(6)各ドライブロールのロール径, ギア比を表示させ, ロール径変更時には周速表示, 回転数指令值を自 動的に修正する。

(7)ドライブ装置の故障時のトレースバックデータ表 示

(8)リアルタイムトレンド表示

(9)ヒストリカルトレンド表示/ヒストリカルデータ 表示

(10)アラームサマリ表示

(11)アラームイベント表示

そのほか, 主機ドライブと補機を中央操作室から集中 的に運転・停止操作する機能をもたせることも可能で, 操作性を高めている。また AI 機能と結合させプロセ スの分析, 診断化へと発展していくことができる。 


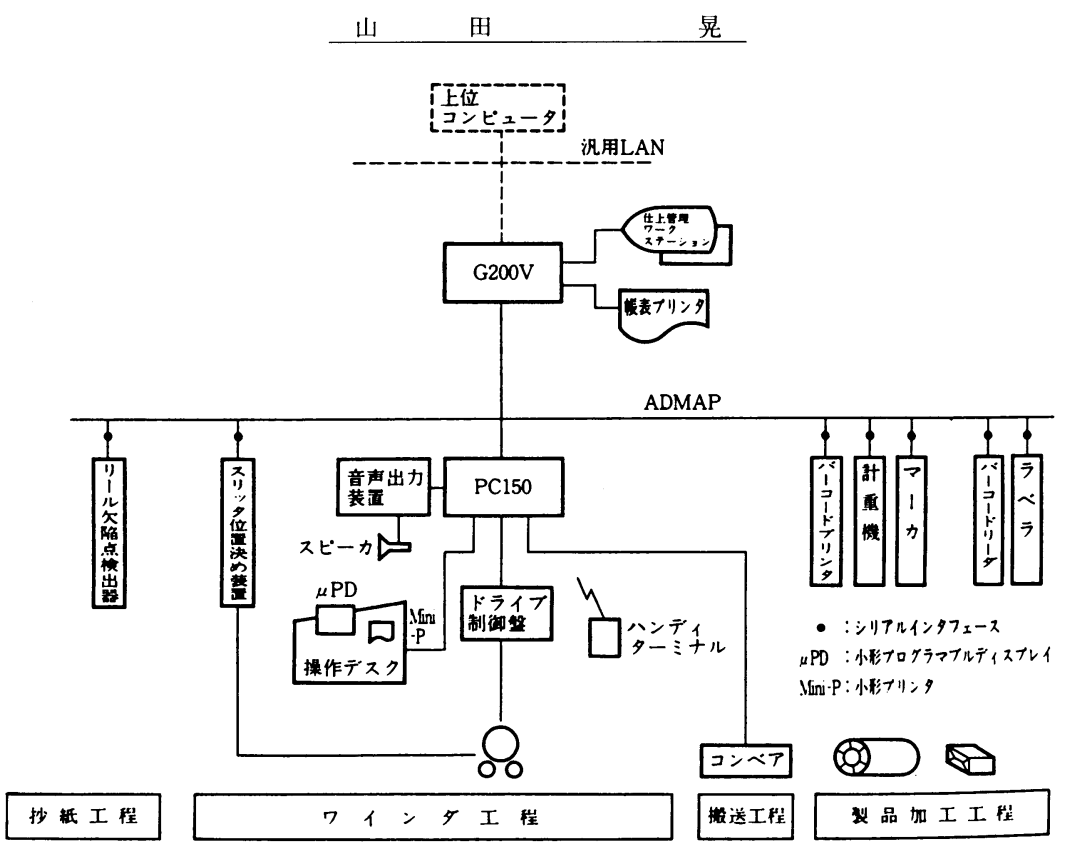

図 3 ワインダー仕上げ管理システム

\section{2 最新鋭ドライブ装置}

従来の可変速ドライブの全デジタル化は制御の高精 度化を主眼として図られてきたが，最近では，特にプ ロセスラインにおいて, CIM 化の要求から上位 $\mathrm{CPU}$ との制御デー夕の迅速な受渡しの必要性が高まり, ま たダウンタイムミニマム化のための RAS 機能強化の 要求等から, さらに高性能の可変速ドライブ装置の出 現が望まれていた。

当社ではこれらの要求に応えるため直流・交流共通 のコンセプトでシステムの拡張性に富み, 操作性・保 守性を強化した可変速ドライブ装置を $\mu / \mathrm{H}$ シリーズ として製品化したのでその特徴を紹介する。

(1) ローダ機能

ローダは組込み形のキーボード（24キー）と液晶 (LCD) 表示器より構成され, 経験の少ない人でも簡単 に操作できるよう次のような工夫をとっている。

・キーボードの操作手順を表示

・データやアドレスのコメントを表示

・各種データを工学単位で取り扱える

(2) メモリーカード機能

設定デー夕や故障発生前後の各種制御デー夕（基準, フィードバック等) のセーブ・ロードがメモリーカー ドを用いて簡単に，かつ高速に出来る。

(3) サポートシステム

メインテナンスッールとしてラップトップパソコン で試験・調整・保守をサポートするシステムを用意し た。
このッールはローカルでパソコンとドライブ装置を 通信回線 (RS-232 C) で結び故障時のセービングデー 夕の波形表示が可能で, 万一の故障発生時の復旧・解 析にも威力を発揮する。

またオートチューニング機能も用意されており，ス テップ応答表示機能とあわせて試運転時の早期立ち上 げが可能で調整レスを指向している。

(4) 設置スペースミニマム化

制御盤をフロントサービス化し，電気室の設置ス ペースを大幅に削減した。( $30 \% \sim 60 \%$ 削減…当社従来 比)

（5）制御性能の向上

$\mu / \mathrm{H}$ シリーズではブラシレスレゾルバによる高精 度デジタル制御に加えてシミュレータ追従制御を装備 しており，負荷のインパクトドロップや軸振動に強い 制御性能を発揮する。

またオフコータマシンなど揄速性を要求される用途 向けに慣性補償制御も装備しており優れた加減速揃速 特性を有している。

\section{3 その他の構成要素}

抄紙機駆動システムを構成するその他の要素として 以下のものがある。

(1) $\mu \mathrm{PD}$

操業現場に設置される操作机には, パネルディスプ レイとして $\mu \mathrm{PD}$ (ELディスプレイ 有効表示エリア $192 \mathrm{~mm} \times 120 \mathrm{~mm})$ を装備し，操作机のインテリジェ ント化，コンパクト化を四り表示器の機能をもたせて 


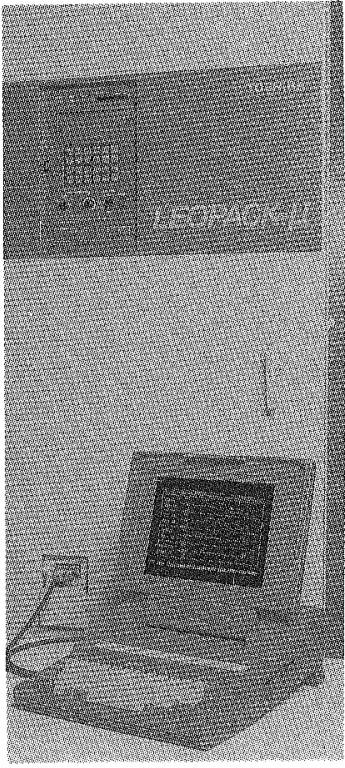

図 $4 \mu / \mathrm{H}$ 制御盤外観

いる。

\section{（2）MCC 伝送装置}

抄紙機の補機に使われる電動機の開閉制御装置であ るコントロールセンタなどの補機盤あるいは機側盤に おいても，主駆動装置に対応したデジタル化が図られ ている。MCC 伝送装置によりシーケンサと接続し運 転監視の合理化ができ，さらにADMAP上にデータ をのせれば中央監視も可能となる。

\section{4. $\mathrm{AC}$ ドライブ装置の動向}

マシンドライブを構成するドライブ装置自体に目を 向けると交流ドライブ化への大きな流れが見えてくる。

1970 年にサイリスタモータ, 1979 年にベクトル制御 採用のサイリスタインバータを適用した抄紙機（いず れも世界初)に始まり, 最近の GTO インバー夕適用の 抄紙機に至るまで, 当社は常に最新の技術開発に力を 入れ，パイオニアの役割を果たしてきた。自己消弧形 電力用半導体素子の大容量化 (高電圧・大電流) ・高速 化は近年急速に発展したもので, 特に 1986 年に全デジ タル型インバー夕を納入以来, 電気品の技術革新と相 まって ACドライブ化が飛躍的に普及した。このよう に最近の ACドライブは自己消弧素子の進歩とマイク ロコンピュー夕技術の普及により, 電流形インバー夕 $\rightarrow$ 電圧形インバータ, PAM $\rightarrow$ PWM 制御, アナログ 制御 $\rightarrow$ デジタル制御への移行が顕著である。

以下では最新のベクトル制御を採用したGTOによ る抄紙機ドライブを紹介する。

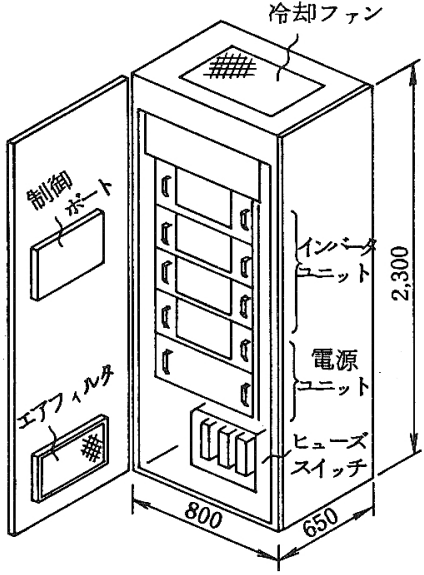

図 5 1,000 kVA GTO インバータ盤構造

4.1 GTO インバータの抄紙機ドライブへの適用 GTO (ゲートターンオフサイリスタ) はゲート電流 の極性を切り換えるだけでターンオフを行える素子で, 自己ターンオフ機能を保有しないサイリスタの最大の 欠点を補う素子として注目を集めていた。

当社では，国内最大級の高速新聞抄紙機にこの GTO を適用したインバー夕装置を製作中である。 GTO インバータを適用したメリットを以下に示す。

（1）インバー夕機種の統一が可能

小容量機にGTR インバータ, 中, 大容量機にGTO インバー夕を適用することにより，小容量から大容量 までを電圧形 PWM インバー夕で統一でき，このため にモー夕設計上の制限が少なくエンジニアリングが容 易となる。

（2）インバー夕供給電源はグループ単位の共通直流 電源が適用可能

従来の電流形サイリスタインバータでは，インバー タとコンバータが 1 対 1 で対応しているため, イン バータの数だけコンバータが必要となる。

それに対して電圧形 PWM インバータでは，グルー プ単位でコンバー夕を共通にでき，かつ直流電源は単 独にエンジニアリングできる。

\section{5. マシンドライブの将来の動向}

ACドライブにはベクトル制御を実用化してきたが， さらに高性能化のためべクトル制御の改良研究がつづ けられている。またセンサレスベクトル制御方式につ いても研究・開発し一部実用を開始している。

半導体素子としては, GTOとともに静音型イン バータに利用されている IGBT (Insulated Gate Bipolar Transister) が容量的に GTRの領域に達し，ポス 
トGTR インバータとして製品化が促進されることが 予想される。

各ドライブ装置機能を見ると, $\mu \mathrm{CPU}$ 等高速デジ夕 ル演算素子の出現は現代制御理論の具体化を容易にし, 非干渉制御/モデル規範適応制御等の実用化や, 自己 調整機能 (オートチューニング)/自己故障診断機能 (RAS 機能・AI 応用) の拡充を一層進展させていく。 更に伝送機能のドライブ装置への組み込みは, システ ム LAN との接続によりドライブ装置がシステム構成 要素部品となり, 伝送容量拡大・高速化はその傾向を 高めつつある。

一方, 主幹ドライブコントローラは, 電気制御とし ての高速度演算・シーケンス制御と計装としてのルー プ制御 (PID) とを兼ね備えた IE 融合コントロールス テーションとマンマシンインターフェイス (MMI) が 実現され, 中小規模システムでは 1 台のコントローラ でIE 制御が可能となり, MMIも一元化される方向に ある。

こうした情報の一元化に伴い, 下位制御機器との データ授受が増加するため, フィールドネットの充実
化が進み，またプロセス周りの各メーカ機器との接続 の必要性から, MAPの採用によるオープンシステム 化が加速されるであろう。

\section{6. むす び}

抄紙機駆動システムとして, 交流可変速ドライブ制 御装置及び最新鋭デジタル制御を駆使した新システム を紹介した。デジタル化, 伝送化により高信頼性のシ ステムであることはもちろん, ミルワイド化への拡張 性をもち，また操業効率向上を目指したシステムであ る。今後は操業支援機能の拡大, $\mathrm{AI}$ 技術の適用などの 付加価值を更に高めたシステムの供給に努める所存で ある。

このような技術の進歩は, いずれも紙パルプ産業の 設備を計画, 施行, 維持, 運用されるユーザ各位の貴 重な各種ノウハウをべースとする暖かいご指導と新し い技術のご採用により初めて実現したものであり，こ の機会に厚くお礼申し上げるとともに，本稿が今後の 新しい設備計画の一助となれば幸甚である。 